\title{
Open lung biopsy performed in idiopathic pulmonary fibrosis is a safe procedure
}

\author{
Tomasz Marjański ${ }^{1}$, Joanna Halman ${ }^{1}$, Sonia Taniewska ${ }^{1}$, Natalia Burzyńska ${ }^{1}$, Anna Piekarska ${ }^{1}$, \\ Wioletta Sawicka \\ ${ }^{1}$ Thoracic Surgery Department, Medical University of Gdansk, Poland \\ ${ }^{2}$ Department of Anaesthesiology and Invasive Care, Medical University of Gdansk, Poland
}

Kardiochirurgia i Torakochirurgia Polska 2017; 14 (4): 236-240

\begin{abstract}
Introduction: Idiopathic pulmonary fibrosis (IPF) is an interstitial lung disease with a fatal prognosis. The diagnosis is made on the basis of high-resolution computed tomography and histological examination in selected cases.

Aim: To determine the risk of complications of open lung biopsy performed in patients with IPF.

Material and methods: We performed a retrospective analysis of 51 patients who underwent diagnostic excision of pulmonary parenchyma due to IPF in the period 1995-2014. We assessed the complication rate, length of drainage, postoperative period and 30-day mortality. We compared the results of treatment in the groups of patients operated on with thoracotomy and videothoracoscopy.

Results: The mean age of patients was 58 (47\% female, $53 \%$ male) forced vital capacity (FVC) was $81 \%$, forced expiratory volume in $1 \mathrm{~s}\left(\mathrm{FEV}_{1}\right)$ was $80 \%$ and body mass index (BMI) was $27 \mathrm{~kg} / \mathrm{m}^{2}$. Thoracotomies (lateral, muscle sparing or anterior) were performed in 20 patients between 1995 and 2012 and videothoracoscopy in 31 patients operated on in the years 2009-2014. Patients in study groups did not differ considering age $(p=0.40)$, gender $(p=0.81)$, FVC $(p=0.08), \mathrm{FEV}_{1}(p=0.13)$ or $\mathrm{BMI}(p=0.75)$. Postoperative complications occurred in $3.9 \%$ of patients (atrial arrhythmia $1.9 \%$ and recurrent pneumothorax $1.9 \%$ ) with equal incidence in both study groups $(p=0.75)$. Median stay after thoracotomy was 4 days while after videothoracoscopy it was 3 days $(p=0.04)$.

Conclusions: Open lung biopsy performed on patients with IPF is a safe procedure. Open lung biopsy performed through thoracotomy could be as safe as through VATS, however is characterized by longer postoperative stay.

Key words: idiopathic pulmonary fibrosis, wedge excision, biopsy.
\end{abstract}

\section{Streszczenie}

Wstęp: Idiopatyczne włóknienie płuc (IPF) jest postępującą chorobą śródmiąższową płuc charakteryzującą się złym rokowaniem. Rozpoznanie opiera się na kryteriach radiologicznych, typowym obrazie w tomografii komputerowej o wysokiej rozdzielczości i badaniu histopatologicznym fragmentu płuca pobranego w trakcie otwartej biopsji płuca.

Cel: Określenie ryzyka wystąpienia powikłań u chorych poddanych otwartej biopsji płuca z powodu IPF.

Materiat i metody: Retrospektywna analiza wczesnych wyników leczenia 51 chorych poddanych diagnostycznemu pobraniu miąższu płuca z powodu IPF w latach 1995-2014. Oceniono częstość występowania powikłań pooperacyjnych, długość utrzymywania drenażu, czas pobytu pooperacyjnego oraz 30-dniową śmiertelność. Porównano wyniki leczenia w dwóch grupach pacjentów - poddanych zabiegowi z dostępu przez torakotomię i wideotorakoskopię.

Wyniki: W badanej grupie było $47 \%$ kobiet i 53\% mężczyzn w wieku średnio 58 lat, ze średnimi wartościami nasilonej pojemności życiowej (FVC) 81\%, nasilonej objętości pierwszosekundowej $\left(\mathrm{FEV}_{1}\right)$ 80\%, indeksem masy ciała (BMI) $27 \mathrm{~kg} / \mathrm{m}^{2}$. Zabiegi z dostępu przez torakotomię (boczną, oszczędzającą mięśnie lub przednią) wykonano u 20 pacjentów w latach 19952012. U 31 pacjentów operowanych w latach 2009-2014 zabieg przeprowadzono z dostępu wideotorakoskopowego. Pacjenci w obu grupach badanych nie różnili się pod względem wieku $(p=0,40)$, płci $(p=0,81), \operatorname{FVC}(p=0,08), \operatorname{FEV}_{1}(p=0,13)$ i BMI $(p$ $=0,75)$. Powikłania pooperacyjne wystąpiły u 3,9\% pacjentów (migotanie przedsionków 1,9\% i nawrotowa odma opłucnowa $1,9 \%)$, z tą samą częstością w obu grupach $(p=0,75)$. Mediana czasu pobytu pooperacyjnego u pacjentów po torakotomii wyniosła 4 dni, a po wideotorakoskopii 3 dni $(p=0,04)$.

Wnioski: Otwarta biopsja płuca wykonywana z powodu IPF jest bezpieczna. Zabieg z dostępu przez torakotomię wiąże się z podobnym ryzykiem jak w przypadku dostępu wideotorakoskopowego, ale z dłuższym pobytem pooperacyjnym.

Słowa kluczowe: idiopatyczne włóknienie płuc, wycięcie klinowe, biopsja.

Address for correspondence: Tomasz Marjański MD, Thoracic Surgery Department, Medical University of Gdansk, 17 Smoluchowskiego St, 80-952 Gdansk, Poland, phone: +48 5834931 42, e-mail: marjanski@gumed.edu.pl

Received: 15.05.2017, accepted: 21.10.2017. 


\section{Introduction}

Idiopathic pulmonary fibrosis (IPF) is an interstitial lung disease with a fatal prognosis due to progressive pulmonary insufficiency [1]. The diagnosis is made on the basis of high-resolution computed tomography (HRCT) and, in select cases, histological examination [2, 3]. The histologic samples may be obtained by means of bronchoscopic forceps biopsy, bronchoscopic cryobiopsy, transthoracic core needle biopsy or open lung biopsy. Open lung biopsy is an invasive diagnostic method performed most commonly under general anesthesia, and allows one to obtain a sufficient volume of specimen in order to make a precise histologic diagnosis. The procedure is routinely performed by muscle sparing thoracotomy or by video-assisted thoracic surgery (VATS). Previous studies have questioned the safety of open lung biopsies. However, their results often pool all of the interstitial lung diseases, or include patients with poor pulmonary function or with cachexia associated with advanced stage of the disease.

\section{Aim}

Thus, the aim of this study is to evaluate the risk of complications of open lung biopsies performed in the specific population of patients with IPF who have an earlier stage of the disease. Additionally, we will compare the outcomes of muscle sparing thoracotomy versus VATS by examining a historic series of patients and their postoperative variables.

\section{Material and methods}

We performed a retrospective analysis of all patients who underwent operations in the Department of Thoracic Surgery Medical University of Gdansk between 1995 and 2014, a number totaling 12 596. Of these patients, 147 underwent open lung biopsy due to an unknown interstitial lung disease from an ambiguous HRCT result. They were accepted for surgery after referral from a pulmonologist and following diagnostic decisions made during multispecialist team meetings. The first patient that was operated on with a diagnostic intent to confirm the type of interstitial lung disease was in 2001.

The inclusion criteria for the study were: direct suspicion of interstitial lung disease stated by a pneumonologist on the basis of a thorough work-up; a preoperative pulmonary function test of forced expiratory volume in $1 \mathrm{~s}\left(\mathrm{FEV}_{1}\right)>30 \%$, reflecting respiratory function that is not significantly impaired; and a definitive postoperative pathological diagnosis of IPF. Thus, out of the patients who had an open lung biopsy, 51 patients who satisfied these criteria entered the analysis.

All procedures were performed under general anesthesia. In the years 2001-2012, 20 patients were operated on through lateral muscle sparing thoracotomy or anterior thoracotomy. In 19 out of 20 patients from this group, marginal diagnostic excision of the pulmonary parenchyma was performed using a vascular clamp and sutured with monofilament 3-0 or 4-0 absorbable running suture. In one patient from this group, a TA Premium mechanical stapler was used.
The remaining group of 31 patients were operated on between 2009 and 2014 through VATS, where the excision was performed with a EndoGIA mechanical stapler. One chest tube, size 20 to $28 \mathrm{Fr}$, was installed after every procedure. The standard of postoperative care did not significantly differ during the early or late phase of the study period, and is listed as follows. Cefazolin $(2 \times 1.0 \mathrm{~g}$ i.v. $)$ was used as standard antibiotic prophylaxis. Low molecular weight heparin in prophylactic dose, and proton pump inhibitors were administered in the perioperative period. The patients were treated with ketoprofen, paracetamol, metamizole with tramadol or morphine in order to keep the pain below the level of $4 / 10$ on the visual analog scale. No extradural anaesthesia or paravertebral block was routinely performed. The patients received rehabilitation starting on the day of the surgery, and were standing and walking as of postoperative day 1 . In the initial study period (before 2012) the drain was removed when the daily amount of fluid drained was lower than $200 \mathrm{ml}$. Following 2012, the drain was removed if the daily amount of fluid did not exceed $350 \mathrm{ml}$, did not contain blood or chylous fluid, and no air leak was present. In more recent operations, digital drainage devices were used.

\section{Statistical analysis}

Statistical tests were used to compare the two groups. For continuous variables, normal distribution was checked using the Shapiro-Wilk W test. Continuous variables with normal distribution (age, body mass index (BMI), FEV ${ }_{1}$, $\mathrm{FEV}_{1} \%$, forced vital capacity (FVC), FVC\%) were compared using Student's $t$-test, while continuous variables with abnormal distribution (pack-years, time of hospital stay, drainage) were compared with the Mann-Whitney U-test. Discrete variables (sex, number of complications) were compared using the $\chi^{2}$ test. $P$-value $<0.05$ was considered statistically significant.

\section{Results}

The characteristics of all patients in the study are presented in Table I.

We analyzed the study population first as a whole, then in two subgroups: VATS and thoracotomy. Twenty biopsies were obtained via lateral muscle sparing or anterior thoracotomy between 2001 and 2012, while 31 biopsies were obtained through VATS over the years 2009-2014. There were no intraoperative conversions from VATS to thoracotomy in our group of patients. Changes in the frequency of performed types of procedures over the years are presented in Figure 1. The two groups (operative access by VATS or thoracotomy) did not differ as regards age, gender, pulmonary function tests, BMI or prevalence of smokers (Tab. II).

Postoperative variables of the entire study group are presented in Table III. Postoperative complications occurred in 2 out of 51 patients in the study group, or 3.9\%. These included 1 out of 31 patients who underwent VATS (recurrent pneumothorax), and 1 out of 20 patients after thoracotomy (atrial fibrillation) (Tab. IV). There were no perioperative deaths. 
Tab. I. Study population

\begin{tabular}{lc} 
Parameter & Value \\
Number of patients & 51 \\
\hline Mean age [years] & 58 \\
\hline Gender & $\begin{array}{c}\text { Female: } 23(45 \%) \\
\text { Male: } 28(55 \%)\end{array}$ \\
\hline BMI $\left[\mathrm{kg} / \mathrm{m}^{2}\right]$ & 27.2 \\
\hline FEV ${ }_{1}\left[\mathrm{dm}^{3}\right]$ & 2.2 \\
\hline FEV ${ }_{1} \%$ & 80.0 \\
\hline FVC $\left[\mathrm{dm}^{3}\right]$ & 3.29 \\
\hline FVC\% & 80.5 \\
\hline Current of former smokers & $30(59 \%)$ \\
\hline Mean pack years & 19 \\
\hline
\end{tabular}

$\mathrm{FEV}_{1}$ - forced expiratory volume, $\mathrm{FEV}_{1} \%$ - percent of predicted value of forced expiratory volume, FVC - forced vital capacity, FVC\% - percent of predicted value of forced vital capacity

The study subgroups did not differ significantly in number of postoperative complications or duration of drainage after procedures in both groups (Tab. IV). However, the study did reveal a statistically significant difference in postoperative length of stay.

\section{Discussion}

Idiopathic pulmonary fibrosis is a chronic, progressive and fatal lung disease. There is no effective medical treatment, with lung transplant being the only alternative. Diagnostic strategies in IPF and other interstitial lung diseases should be made during the multidisciplinary team meetings [4]. The diagnosis of IPF is based on HRCT and surgical lung biopsy in cases with an ambiguous HRCT result [2]. Only 30-60\% of patients require surgical lung biopsy [5]. On the other hand, the exact pathological diagnosis is stated in only $70-81 \%$ [6].

The incidence of IPF is relatively high among interstitial lung diseases, and its prognosis is overall poor, with a 5-year survival worse than several cancer types. Other interstitial lung diseases, such as idiopathic interstitial pneumonias, have better prognoses and require different therapies; therefore biopsy can affect therapeutic management. Thus, the pathological confirmation of IPF is needed to rule out the possibility of diseases with better therapeutic options and prognoses. As seen in our study, 35\% of patients with

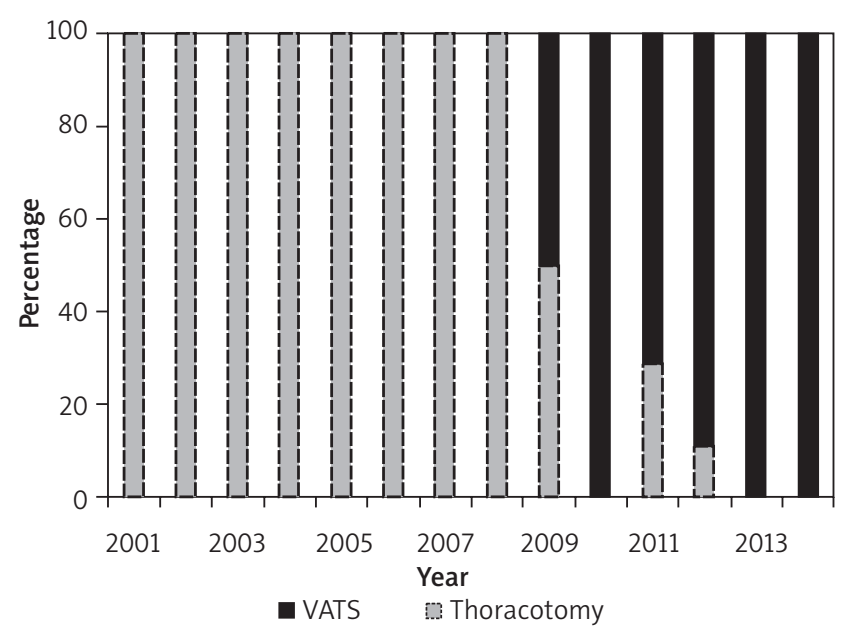

Fig. 1. Procedures performed in the study period VATS - video-assisted thoracic surgery

Tab. II. Comparison of two study subgroups

\begin{tabular}{|c|c|c|c|}
\hline Parameter & $\begin{array}{l}\text { Thoracotomy } \\
\quad(n=20)\end{array}$ & $\begin{array}{l}\text { VATS } \\
(n=31)\end{array}$ & $P$-value \\
\hline Years & 2001-2012 & 2009-2014 & - \\
\hline Mean age [years] & 60 & 57 & 0.40 \\
\hline Sex & $\begin{array}{c}\text { Female: } 9(45 \%) \\
\text { Male: } 11(55 \%)\end{array}$ & $\begin{array}{c}\text { Female: } 15(48 \%) \\
\text { Male: } 16(52 \%)\end{array}$ & 0.81 \\
\hline Mean BMI $\left[\mathrm{kg} / \mathrm{m}^{2}\right]$ & 27.70 & 27.03 & 0.57 \\
\hline Mean $\mathrm{FEV}_{1}\left[\mathrm{dm}^{3}\right]$ & 2.14 & 2.61 & 0.42 \\
\hline Mean FEV $\%$ & 69.9 & 88 & 0.13 \\
\hline Mean FVC $\left[\mathrm{dm}^{3}\right]$ & 3.05 & 3.38 & 0.37 \\
\hline Mean FVC\% & 77.5 & 94.0 & 0.08 \\
\hline $\begin{array}{l}\text { Current of former } \\
\text { smokers }\end{array}$ & 14 & 16 & 0.15 \\
\hline Mean pack years & 9 & 14 & 0.39 \\
\hline
\end{tabular}

$\mathrm{BMI}$ - body mass index, $\mathrm{FEV}_{1}$ - forced expiratory volume, $\mathrm{FEV}_{1} \%$ - percent of predicted value of forced expiratory volume, FVC - forced vital capacity, FVC\% - percent of predicted value of forced vital capacity

Tab. III. Postoperative period (study population, $n=51$ )

\begin{tabular}{lc}
\hline Drainage time [days] & 2 \\
\hline Number (\%) of complications & $2(3.9)$ \\
\hline Postoperative length of stay [days] & 3 \\
\hline
\end{tabular}

Tab. IV. Postoperative period in study subgroups

\begin{tabular}{|c|c|c|c|}
\hline Variable & Thoracotomy & VATS & $P$-value \\
\hline Drainage time [days] & 2 & 2 & 0.50 \\
\hline Number of complications & $\begin{array}{l}1 / 20(5 \%) \\
\text { Atrial fibrillation }\end{array}$ & $\begin{array}{c}1 / 31(3.2 \%) \\
\text { Recurrent pneumothorax }\end{array}$ & 0.75 \\
\hline Length of postoperative hospital stay [days] & 4 & 3 & 0.04 \\
\hline 30-day mortality & 0 & 0 & - \\
\hline
\end{tabular}

VATS - video-assisted thoracic surgery 
radiologically suspected interstitial lung diseases ultimately had IPF histologically confirmed, which means that therapeutic decisions for the majority of patients were affected.

Controversies present in previous studies about the safety of surgical lung biopsy may be due to the common reporting of surgical lung biopsies performed for all interstitial lung diseases. These studies have calculated that open lung biopsy is a procedure with a high risk of complications between 7 and 19\% [6-8]. The most commonly mentioned complications are persistent air leak, readmission within 30 days, prolonged mechanical ventilation, and pneumonia. However, this may not reflect the exact risk of the procedure in varying clinical characteristics of different types of interstitial lung diseases. We decided to present the results of this surgical diagnostic procedure in the homogeneous group of patients with idiopathic pulmonary fibrosis in an early stage of the disease.

Our study results demonstrate that open lung biopsy, whether VATS or thoracotomy, performed in IPF possesses an acceptable level of complication risk in groups of patients who have an early stage of the disease without significant impairment of respiratory function. This procedure is not associated with prolonged hospital stay and may be safe and valuable in the diagnosing of IPF. The complications reported in our series are not typical for open lung biopsies but rather for resections of the pulmonary parenchyma. The low rate of complications (3.9\%) reflects the early stage of the disease in which patients were accepted for diagnostic surgery.

The reported perioperative mortality (usually defined as 30 -day) in interstitial lung diseases varies from $3 \%$ to $17 \%$ [6-10], but is most commonly reported below $10 \%$. This is likely in populations of high-risk patients with end-stage respiratory insufficiency or with significant concomitant diseases. We present the results of treatment of a completely opposite group of patients with IPF. Relatively young patients with good pulmonary function tests who are not cachexic are excellent surgical candidates for this kind of diagnostic procedure. Currently the postoperative period rarely exceeds 3 days, and the mortality rate is as low as 0 due to the rarity and mildness of complications.

On the basis of a recently published paper [11], attempts are made to implement a risk scoring system for surgical biopsies in interstitial lung disease. The data allow identification of high-risk patients with an increased 90-day mortality. The lowest grade of the proposed scoring system is related to perioperative risk as low as $2 \%$, while the top risk tier is associated with $86 \%$ risk of 90 -day mortality. This scoring system obviously guides the decisions concerning the acceptance of open lung biopsies in early IPF patients. However, lack of validation studies is a barrier to routine implementation of the abovementioned scale.

Nonetheless, we would advocate that in the case of patients with end stage IPF, open lung biopsy should be avoided. Recent advances in endoscopic techniques or a core biopsy are the only diagnostic options for these patients. It should be taken into consideration that around half of the patients do not benefit from open lung biopsies because the pathological result of the examination does not imply a change in medical treatment [6]. This number may be more pronounced in patients with end stage of the disease. Extremely high perioperative mortality in these patients should be the reason for assuming open lung biopsy as a contraindicated procedure.

In addition, our retrospective analysis demonstrates the safety of performing surgical lung biopsy in patients with IPF through either thoracotomy or VATS. Although VATS is currently the procedure of choice in open lung biopsy, due to a long period of retrospective analysis, we had an opportunity to compare patients who underwent either procedure in terms of duration of drainage, the number of postoperative complications, postoperative length of stay and 30-day mortality. The only difference between groups occurred in postoperative length of stay, which may result from changes in the frequency of the types of procedures performed over the years. As proven by numerous studies, VATS is better tolerated and associated with reduced length of hospital stay [12]. Nevertheless, our results have shown that open lung biopsy performed through thoracotomy could be just as safe as through VATS. The authors' aim of presenting the results of treatment of patients who underwent thoracotomy is to underline the safety of thoracotomy in a high volume center, not to promote the procedure as an alternative to VATS.

This study has several limitations. The retrospective character of this analysis does not offer the opportunity to draw exact conclusions with a high level of confidence. The relatively small numbers of analyzed patients may also raise some bias. However, we assume that the gathered data support the drawn conclusions. The advantage of the study is presenting the results of diagnostic surgery in a homogeneous group of patients with IPF with good pulmonary function tests, allowing for a safe intervention.

\section{Conclusions}

In generally fit patients with normal pulmonary function tests, open lung biopsy performed for IPF is a safe procedure. Open lung biopsy performed through thoracotomy could be as safe as through VATS, but it is characterized by longer postoperative stay.

\section{Acknowledgments}

The authors would like to thank Jingru Miao, McGill University, Faculty of Medicine, for his revision of the manuscript.

\section{Disclosure}

Authors report no conflict of interest.

\section{References}

1. Ley B, Collard H, King T. Clinical course and prediction of survival in idiopathic pulmonary fibrosis. Am J Respir Crit Care Med 2011; 183: 431-440.

2. Raghu G, Collard H, Egan J, Martinez F, Behr J, Brown K, Colby T, Cordier J, Flaherty K, Lasky J, Lynch D, Ryu J, Swigris J, Wells A, Ancochea J, Bouros D, Carvalho C, Costabel U, Ebina M, Hansell D, Johkoh T, Kim D, King T, Kon- 
doh Y, Myers J, Müller N, Nicholson A, Richeldi L, Selman M, Dudden R, Griss B, Protzko S, Schünemann H. An official ATS/ERS/JRS/ALAT statement: idiopathic pulmonary fibrosis: evidence-based guidelines for diagnosis and management. Am J Respir Crit Care Med 2011; 183: 788-824.

3. Branley H, Lake F. 2008 British guidelines on the management of interstitial lung diseases. What are the key new messages for clinical practice? Pol Arch Med Wewn 2009; 119: 112-114.

4. Thomeer M, Demedts M, Behr J, Buhl R, Costabel U, Flower CD, Verschakelen J, Laurent F, Nicholson A, Verbeken E, Capron F, Sardina M, Corvasce G, Lankhorst I. Multidisciplinary interobserver agreement in the diagnosis of idiopathic pulmonary fibrosis. Eur Respir J 2008; 31: 585-591.

5. Kaarteenaho R. The current position of surgical lung biopsy in the diagnosis of idiopathic pulmonary fibrosis. Respir Res 2013; 14: 43.

6. Blackhall V, Asif M, Renieri A, Civitelli S, Kirk A, Jilaihawi A, Granato F. The role of surgical lung biopsy in the management of interstitial lung disease: experience from a single institution in the UK. Interact Cardiovasc Thorac Surg 2013; 17: 253-257.

7. Kreider M, Hansen-Flaschen J, Ahmad N, Rossman M, Kaiser L, Kucharczuk J, Shrager J. Complications of video-assisted thoracoscopic lung biopsy in patients with interstitial lung disease. Ann Thorac Surg 2007; 83: 1140-1144.
8. Lettieri C, Veerappan G, Helman D, Mulligan C, Shorr A. Outcomes and safety of surgical lung biopsy for interstitial lung disease. Chest 2005; 127: 1600-1605.

9. Hunninghake G, Lynch D, Galvin J, Gross B, Müller N, Schwartz D, King T, Lynch J, Hegele R, Waldron J, Colby T, Hogg J. Radiologic findings are strongly associated with a pathologic diagnosis of usual interstitial pneumonia. Chest 2003; 124: 1215-1223.

10. Utz JP, Ryu JH, Douglas WW, Hartman TE, Tazelaar HD, Myers JL, Allen MS, Schroeder DR. High short-term mortality following lung biopsy for usual interstitial pneumonia. Eur Respir J 2001; 17: 175-179.

11. Fibla JJ, Brunelli A, Cassivi SD, Deschamps C. Aggregate risk score for predicting mortality after surgical biopsy for interstitial lung disease. Interact Cardiovasc Thorac Surg 2012; 15: 276-279.

12. Scott W, Allen M, Darling G, Meyers B, Decker P, Putnam J, McKenna R, Landrenau R, Jones D, Inculet R, Malthaner R. Video-assisted thoracic surgery versus open lobectomy for lung cancer: a secondary analysis of data from the American College of Surgeons Oncology Group Z0030 randomized clinical trial. J Thorac Cardiovasc Surg 2010; 139: 976-981. 